A Journal of Culture, English Language, Teaching \& Literature ISSN 1414-3320 (Print), ISSN 2502-4914 (Online)

Vol. 21 No.1; June 2021

Copyright $@$ Soegijapranata Catholic University, Indonesia

Alienation and Hopes in Indonesian Migrant Worker Literature Work

${ }^{1}$ Muna Yastuti Madrah and ${ }^{2}$ Destary Praptawati

${ }^{1}$ Department of Islamic, History and Culture, Faculty of Islamic Studies, Universitas Islam Sultan Agung, Semarang, Indonesia

${ }^{2}$ English Literature Study Program, Faculty of Language and Communication Science,

Universitas Islam Sultan Agung, Semarang, Indonesia email: ${ }^{1}$ munamadrah@unissula.ac.id; ${ }^{2}$ destary@unissula.ac.id

Received: 19-10-2020

Accepted: 08-06-2021

Published: 16-06-2021 


\title{
Alienation and Hopes in Indonesian Migrant Worker Literature Work
}

\author{
${ }^{1}$ Muna Yastuti Madrah and ${ }^{2}$ Destary Praptawati \\ 1'munamadrah@unissula.ac.id; 2destary@unissula.ac.id \\ ${ }^{1}$ Department of Islamic, History and Culture, Faculty of \\ Islamic Studies, Universitas Islam Sultan Agung, Semarang, \\ Indonesia \\ ${ }^{2}$ English Literature Study Program, Faculty of Language and \\ Communication Science, Universitas Islam Sultan Agung, \\ Semarang, Indonesia
}

\begin{abstract}
Female Indonesian migrant domestic workers (DMWs) often get a negative predicate both in Indonesia and in destination countries. For example, DMWs in Singapore are treated unequally by Singaporean society, in Indonesia, as well, their work is seen as a lowly job. They can be categorized as a marginal group. Marginals are marginalized people whose rights are ruled out by people that have power. Hence, they find it difficult to adapt to their environment and they are always suppressed. The circumstances lead to the feeling of alienation for DMWs. The alienation they have experienced is often ignored as a reality of the life of migrant workers. This study takes the object of poetry by Female Indonesian DMWs in Singapore. It explores how marginalization and alienation are expressed in literary work by female domestic migrant workers. This study, also analyzes how the expression of literary work can be functioned as a medium to voice alienation and to overcome its problem. This research used textual analysis, including the application of semiotics and narratology to see the marginalization and alienation faced by the migrant workers which are represented through a literary work. As complementary data, virtual interviews with the author of poetry was conducted.
\end{abstract}

Key words: domestic migrant workers, poetry, alienation, literary works 


\begin{abstract}
Abstrak: Pekerja migran perempuan Indonesia yang bekerja pada sektor domestik masih sering mendapatkan predikat negatif baik di Indonesia maupun pada masyarakat di Negara tujuan. Sebagai contoh pekerja migran di Singapura tidak dianggap setara dengan masyarakat Singapura, namun demikian juga pekerjaannya dianggap rendah oleh masyarakat Indonesia. Mereka dapat dikategorikan sebagai kelompok marginal. Marginal adalah orang-orang yang dipinggirkan, yang mana hak-hak mereka dikesampingkan oleh para penguasa yang memiliki kekuasaan. Pada keadaan yang demikian, mereka sulit untuk beradaptasi dengan lingkungannya, dan kondisi mereka yang selalu ditekan. Hal tersebut seringkali memunculkan perasaan keterasingan bagi pekerja migran. Keterasingan yang mereka alami selama ini dan sering diabaikan sebagai realitas kehidupan pekerja migran. Dengan mengambil objek kajian puisi-puisi karya pekerja migran yang bekerja pada sektor domestik di Singapore, studi ini akan mengekplorasi secara mendalam bagaimana marginalisasi dan alienasi diekspresikan dalam karya sastra oleh pekerja migran wanita. Studi ini juga akan menganalisa bagaimana ekspresi melalui karya sastra dapat berfungsi sebagai media yang menyuarakan alienasi pekerja migran dan mengatasi problematika alienasi. Penelitian ini menggunakan analisis tekstual, termasuk penerapan semiotika dan narratologi untuk mengetahui pengalaman apa yang disajikan oleh pekerja migran. Sebagai data pelengkap, wawancara dengan dengan penulis dilakukan secara virtual.
\end{abstract}

Kata kunci: Tenaga kerja wanita, alienasi, sastra, puisi, marjinalisasi

\title{
INTRODUCTION
}

Female Indonesian Domestic Migrant Workers, hereafter DMWs, often receive negative predicates both in Indonesia and in destination countries. For example, DMWs in Singapore are not considered equal to the Singaporeans, however, their work is considered as low-skilled workers by the Indonesian people (Rahajeng et al., 2018). They can be categorized as marginal groups. The concept of marginality demands the integration of the concept of poverty with the concepts of social exclusion, geography, and ecology. Difficulty in reaching people on the periphery of the system is explained by a range of 
Madrah, Y.M. \& Praptawati, D., Alienation and Hopes in Indonesian Migrant 41 Worker Literature Work

distances, that is, physical distance such as being in a remote or harsh environment, social distancing, being discriminated against, or having no rights or access, services, and opportunities (Von Braun \& Gatzwiler, 2014). This situation can create a feeling of alienation for migrant workers.

The alienation or feeling of alienation they experience is often ignored as a reality of the migrant workers' life. The concept of alienation has been widely discussed by social theorists. Marx analyzed it from the emergence of a capitalist society. Marx saw the injustice that existed in the relationship between society and the capitalist economic system (in Ritzer \& Goodman, 2004). According to Marx, labor in a capitalist society is alienated from their productive activities. Alienation occurs from the transformation of everything into commodities (Alonso \& Meszaros, 1975). Berger \& Luckman call it reification, which is when the institutional structure is assumed to have taken its own life independently of human intentions and needs, and society is perceived as something separate from its creation (in Seidman, 2013). Alienation occurs when social needs are not met and humans feel alienated from other humans. Humans will increasingly find gaps between need and the capacity to meet those needs (Storey, 2014). This gap is produced by the capitalist system which is increasingly fascinating the world.

The capitalist system creates a gap between human needs and the capacity to meet those needs. DMWs potentially experience multiple vulnerabilities, firstly because of the global capitalist system and, second because they are immediately uprooted from their cultural social roots. Those are the causes of the strong feelings of alienation experienced by migrant workers. However, alienation is not a fixed condition. To get out of feeling alienated, humans also continue to carry out negotiation strategies, so that the conditions or levels of alienation experienced can be changed (Storey, 2014). One example can be seen from the poem titled "The Oppressed Commoners" by Ratinia Fatmawati below:

The pitful little small-timers

Defending themselves shouting for justice

Pleading for rights as the oppressed commoners

Although it has been widely discussed, there have not been many contributions in the field of literature. This article attempts to apply recent theoretical contributions to the literature coming from Indonesian female migrant workers to gain a better understanding of how alienation manifests in 
literary works. The marginalization of female migrant workers cannot always be expressed and voiced because of their alienated situation. This article will analyze how a group of Indonesian female migrant workers in Singapore is trying to voice their alienation as well as their hopes through literary works. Their works are in English and published in an anthology of literary works by Indonesian female migrant workers in Singapore with the title "Familiar Stranger: Anthology of Poems and Short Stories by Indonesian Migrant Workers". It was published by the Directorate of Research and Community Engagement, the University of Indonesia in collaboration with a Singapore non-profit organization voice of Singapore invisible hands.

This study seeks to see how cultural strategies are carried out by migrant workers to create spaces of expression. The creation of space through cultural strategies cannot be separated in the study of the sociology of everyday life (Lefebvre, 1947, 1961, 1981; in Storey, 2014). In sociology, day-to-day studies have been underdeveloped, even though they are very strategic as a research approach, especially on marginalized groups such as migrant workers. The creation of spaces for the expression of literary works in the context of cultural strategies is used as a strategy of resistance and negotiation by this group of Indonesian migrant workers to overcome alienation and initiate social ties with fellow Indonesians and residents. Through a sociological analysis of the literary works of DMWs, we will explore how marginalization and alienation occur among DMWs in Singapore. Besides, we will try to see how the expression of literary works can function as a medium to voice alienation. DMW' work shows there are cultural gaps that can be used as a strategy to voice and to express both positive and negative experiences when becoming DMWs.

\section{LITERATURE REVIEW}

Research on the relationship between migration and cultural capital in migrant workers was carried out by Erel (2010), Samaluk (2015), and Nugroho (2018). Erel researches the migration of cultural capital of migrant workers. Erel argues that the migration process produces a new way of producing and reproducing cultural capital, more than just a reflection of the power relations of both the country of origin and the destination country. Migrants create a validation mechanism of their cultural capital, negotiating the ethnic majority, institutions, and networks (Erel, 2010). Erel uses the life story method to see how Turkish migrants in England and Germany create cultural capital outside 
Madrah, Y.M. \& Praptawati, D., Alienation and Hopes in Indonesian Migrant 43 Worker Literature Work

of their cultural practices. The role of intra-ethnic power relations in creating distinction practices with residents, and how inter-ethnic relations reflect the way migrants create cultural capital.

Samaluk's research (2015) discussed the migration strategy and struggle of Slovenian and Polish workers to acquire and change capital in the process of transnational exchange upon their arrival in the UK. Samaluk reveals the symbolic power of neo-colonial guiding the strategy, from those who wish to migrate to newcomers, to acquiring a nationally recognized form of cultural capital by taking advantage of job training in the West. This training is introduced by the services of intermediary agencies which they think are reliable. Nugroho (2018) specifically looks at the Indonesian migrant workers-student phenomenon in South Korea, his ethnographic study explains how Indonesian migrant worker-students negotiate their ambivalent identity as migrant workers and as students. Regardless of their hard life working or studying and socially different societies, they have managed to show resilience to strive for a better future. Nugroho stressed that the new rhythm of life for Indonesian migrant workers and changing identities provides new opportunities and friction in their workplaces, especially where companies do not allow the workers to study even though they study not during their working hours. In the midst of this, they are also using the higher education they experienced at UT Korea as a way to increase their social mobility and to conceptualize a hybrid migrant identity. Nugroho's research underscores the diverse, complex, and even insecure identities that emerge in the process of crossing boundaries between workers and students. The experiences of these migrant workers contribute to the blurring of boundaries between knowledge mobility and labor migration in Asia (Nugroho, 2018b).

Meanwhile, Shervington (2019) states that migration is a radical attempt to immerse oneself in other cultures. In such a position, feelings of alienation can dominate the existence of migrants, due to the displacement of their spatial and psychological references. Shervington analyzes the idealized migrant figure in the new migrant subject with Jaques Lacan's "fantasy" approach. Migrants create an unrealistic standard of success in an economic system where few can exceed their class category. As a result, the fantasy of the "ideal migrant" serves to hide another environment that is formed through the process of migration from one country to another. Alternative idealization can be found in creating an environment in which migrants can talk openly about their struggles in a new home country and relate to isolation from one another, thereby encouraging a level of authentic solidarity. 
Sun's research (2012) helped us find the relationship between literary works and the working class. Sun researched the dagong community in China. A literature genre has emerged from this community. They documented the devastating effects of industrial machinery on the bodies and souls of rural migrant workers. Sun examined the paradoxical process of class formation and class dissipation through debate and interpretation around worker's poetry from cultural elite institutions and worker-poets themselves. Sun focused on the class consciousness built by the dagong community. According to Sun, the worker-poet is faced with two strange situations. First, being involved in the production or consumption of poetry usually requires good education and free time, this is in contrast to the fact that dagongs live in reality as rural migrant factory workers working 12 hours per day. Besides that, the educational background of dagong is not higher education. The second is related to the labeling given by academics to dagong poetry. This ongoing debate includes the question of the proper labeling of poetry written by migrant workers, the definition of dagong poetry, the role and purpose of dagong poetry, the standards by which to judge the usefulness of the poetry, as well as the future direction of the dagong poetry. Furthermore, these comments and debates come from both established cultural institutions - academia, literary, and media associations and the working poets themselves. Sun (2012) argues that comments and debates on migrant workers' literary work are class articulations and disarticulations, and those are pointing to the formation of working-class consciousness in contemporary China.

SHE (2014) also researched migrant worker poetry by using textual analysis to find out what kind of experiences is presented by migrant worker poetry. SHE tries to see if the poetry of migrant workers is the voice of the lower class. SHE concludes that negative experiences mainly include narratives of misery, differences between urban and rural areas, as well as daily resistance as one of the most significant themes of migrant worker poetry, the expression of nostalgia changing from external to internal. The word group antonym represents the essence of the poem and the dialectical relationship between negative and positive experiences. The narratological analysis discusses that in facing the amalgamation of mainstream culture, how poets hesitate between being the other with consciousness and being the other without consciousness.

Research on migrant workers concerning capital accumulation and especially related to literary works have not revealed how DMWs create spaces of expression that speak of their alienation and marginalization. So this research will complement the existing research related to DMWs by providing new 
Madrah, Y.M. \& Praptawati, D., Alienation and Hopes in Indonesian Migrant 45 Worker Literature Work

perspectives in finding solutions to problems faced by Indonesian migrant workers.

\section{METHOD}

This study uses a qualitative research approach with descriptive analysis. Qualitative research emphasizes the socially constructed nature of reality, the relationship between the researcher and the research subject, and the situation under investigation (Denzin \& Lincoln, 1994). This research tries to use textual analysis, including the application of semiotics and narratology (Ermawan et al., 2019), to find out what experiences are presented by "migrant worker poetry", and to discuss whether "migrant worker poetry" is the voice of the lower class itself or not. In other words, this study tries to see if the real lower class can be seen through this work. Through symbolic coding and word frequency, it can be concluded that negative experiences mainly include narratives of misery, urban and rural areas differences, and daily resistance.

\section{RESULTS AND DISCUSSIONS}

\section{A. Results}

Literature is not only seen as a creative and imaginative work but also seen as educational entertainment. Literature is rarely used specifically to understand people's life (Salam, 2008). However, literary work is a reflection of the life of society in its era. Despite the imaginative work of the author, literary works cannot be separated from the things that happen around the author (Kartikasari et al., 2013). In the "Familiar Stranger: Anthology of Poems and Short Stories by Indonesian Migrant Workers", we will first look at how alienation is depicted in the works of migrant workers. One that will be raised in this article is Eli Nur Fadilah's poem entitled the voices of these invisible hands.

If I could speak

I would say, I am tired

Of being used

Dishwashing detergent and bleaching 
Make me sick, sometimes bleed

If I was not here, would they survive?

I try my best all the time

Yet, I still get yelled at

...

So, I will keep going on

Working with stranger

And hiding my anger

They see me but they don't recognize me

I will one day they will understand the hands that organize their life

I wish they could listen to the voice of these invisible hands

The early stanza of Eli's Poem says: wish she could speak, showing that in real life, it is very difficult for these migrant workers to voice their opinions. All kinds of works and the various chemicals she used in household chores had made her tired and sick. Also, other injuries from work cannot be counted. So, the poet thinks that if they (domestic workers) are not in the employer's house, will the employer be able to survive? However, their hard work does not get any appreciation from the employer.

In another poem by Windu Madness (pen name) entitled "New in Singapore", it can be seen how DMWs express themselves as newcomers who are very not familiar with Singapore's social background that is different from their origin.

Everyone speaks English and Singlish

While I feel like an alien

In the world of technology, I wonder why is that Marlion peeing through his mouth

Everyone is walking so fast

It is like half running

Putranto (2011) describes alienation as a paradoxical experience of isolation, for example, the feeling of loneliness in crowds. The experience of alienation is experienced by DMWs in Singapore. Working in the house (domestic realm) every day, but feeling isolated and alone. DMWs uprooted from their 
Madrah, Y.M. \& Praptawati, D., Alienation and Hopes in Indonesian Migrant 47 Worker Literature Work

socio-cultural roots to enter this experience when they encounter the splendor of their employer's apartments with all modern equipment, but those types of equipment are new things for them. Eli described it in a poem entitled FO4. In correspondence with Eli, FO4 is the brand of a washing machine in her employer's house. Eli expresses her concern over not being able to repair a machine that may have broken, along with fear of her employer's anger. The situation is very different from her original social background where almost all domestic work is done manually.

$\mathrm{FO} 4$

Two and a half hours I spend

Trying hard to repair

But end up getting tired

And getting out for some fresh air

FO4

I can't continue working

I can't stop thinking

What if my employer is angry?

What will they do to me?

I am starting to worry

In the context of modern life where the social background of the destination country of migrant workers is a developed industrialized country with high individuality, domestic labor is also part of the commodity-exploited capitalist system. The relationship between workers and employers is based on exploitation. Alienation occurs when the relationship between work and human nature is distorted by the capitalist system (Prayoga \& Handoyo, 2014). Marx associated the process of alienation with the capitalist model of production in which man is separated from his product of creation. This is because humans in the capitalist system do not work based on their ideas but they work based on orders and wages given (Modarres, 2005, Ritzer, 2012). The work of DMWs is based on the standard of domestic work given by the employer because they have paid. Meanwhile, the social-cultural backgrounds of DMWs are often neglected and they are considered as if they work like robots that do not need appreciation. The feeling of being alienated is also reflected in the words of DMWs who feel that they have worked for strangers whom they see every day but they don't know. Eli also describes the feeling of 
being alienated from another work in the anthology with the title domestic workers are human too.
$\cdots$
I don't need you to treat me like a twin
Please do not treat me like a servant
I do have my rights,
Even though I make mistakes
I know I get paid
But don't harm me like I've done nothing

It describes the feeling of alienation of DMWs even though they are paid for their work. In this context, the results of their work are in the form of order and cleanliness with standards that exceed the standards of society and culture from the origin country. In a capitalistic society, the concept of alienation is often regarded as taken for granted, as a result of the condition of a class. The feeling of being alienated and the way to overcome the alienation itself are very dynamic. Humans use various strategies to survive, including by creating "space" (Lefebvre, 1991 Storey, 2014). DMWs in Singapore use a cultural strategy by writing it into literary works that can be enjoyed as well as a space to voice their feelings of alienation. The ability to present and be visible in social spaces will overcome the feelings of alienation experienced by these migrant workers.

DMWs tried to get rid of their feeling of alienation by engaging in various self-actualizing activities. In this case, we agreed with Lefebvre. Lefebvre emphasizes the need to criticize everyday concepts (Elden, 2007, Storey, 2014). It is not only trying to understand everyday space but also understanding the extent to which the transformation experienced by female Indonesian domestic migrant workers, from alienated migrant workers to empowered workers. It is also to take advantage of the social space in Singapore to fulfill the basic needs of a sense of belonging in the country where they make a living.

DMWs in this context stand as a minority, migrants who have different economic backgrounds from their employers. Alienation occurs in binary oppositional relations which creates inequality in the majority-minority relationship. New norms will emerge from the dominating party who will be referred to by the dominated (Putranto, 2011). According to Young (2003), 
Madrah, Y.M. \& Praptawati, D., Alienation and Hopes in Indonesian Migrant 49 Worker Literature Work

people who are under alienation come from minorities and become people who are never part of the norm, so they do not have the authority to speak.

In this poem, it can be seen that DMWs describe alienation through the description as follows. First is isolation as an atmosphere in which they are unable to voice their burdens, of course, the workload to the people in their scope of work. Second, alienation is described through the means of work. The third is a feeling of alienation because they are workers who are paid by foreigners. However, feeling alienated does not mean eradicating their hopes and dreams. In their literature, apart from feeling alienated, they also construct expectations as a paradox of feelings of alienation. As in Eli's poem "Sky of Hopes", Eli describes the future as the pulse of life.

Make their future your pulse

And their life your nerve

After all, that will create a rainbow in your eyes

Also, in the poetry verses by Meikhan Sri Bandar entitled "My Dream".

I was still on the ground

But I won't give up

My Dream is my spirit

My spirit is my faith

And My faith is my life

DMWs tried to build social space throughout their literary works. The social space referred to by Lefebvre is a space that is produced in certain ways which becomes a means of thinking and acting (Elden, 2007, Hendra, 2018). Space is always bound by history and time. Lefebvre's concept of space includes the relationship between three aspects, namely, first, "practical space", which is space that is produced daily. Second, the representation of space, that is space in the cognitive sense, and third, "the space of representation" which is symbolization and idealization (Hendra, 2018).

Those can be seen, for example, when DMWs describe the apartment, kitchen, or Singapore as a city, then DMWs describe the space in the context of the practical space of everyday life. This practical space is presented in their 
works. The practical space is, then conceptualized as discourse. Space does not exist physically but it is the result of meaning or representation of space. The present space becomes a verbal system and becomes part of the DMWs' awareness. The third aspect is representational space which, according to Lefebvre, only produces symbolic things. This is what migrant workers in Singapore do, even though they place them in the symbolic space of literary works, but they are quite effective in the space of representation of alienation as well as their hopes of them.

\section{CONCLUSION}

DMWs are alienated not because they work in factories that alienate themselves from the products they make. DMWs experienced isolation as per Marx's theory of alienation, where DMWs were encouraged to work more efficiently by using a variety of sophisticated household equipment, which becomes an instrument for a higher level of service. Alienation also appears in the context of the employer-worker relationship. The class structure that appears in every society allows people to alienate each other (Modarres, 2005), where usually workers are alienated by those who exploit.

However, DMWs try to build a space to voice experiences of alienation as well as dreams and hopes in literary works. Their work is a picture of struggle and productivity. It is the actual usage and experience of space. Lefebvre argues that space is the main place and medium of struggle, and therefore an important political space (Elden, 2007). This shows that actually society and every way of production produce its own space.

\section{ACKNOWLEDGEMENT}

Thank you to UNISSULA for the grant of this research, also thank you to the female migrant poet who is willing to be interviewed for this research.

\section{REFERENCES}

Alonso, J. J. C., \& Meszaros, I. (1975). Marx's theory of Alienation (Issue 40/41). https://doi.org/10.2307/40182273 
Madrah, Y.M. \& Praptawati, D., Alienation and Hopes in Indonesian Migrant 51 Worker Literature Work

Denzin, N. K., \& Lincoln, Y. S. (1994). Handbook of qualitative research. In Handbook of Qualitative Research (Vol. 1).

Elden, S. (2007). There is a Politics of Space because Space is Political. Radical Philosophy Review, 10(2), 101-116. https://doi.org/10.5840/radphilrev20071022

Erel, U. (2010). Migrating Cultural Capital: Bourdieu in Migration Studies. Sociology, 44(4), 642-660. https://doi.org/10.2307/42857433

Ermawan, Fitriana, R., \& Mugiyanti. (2019). Analisis Naratologi Cerpen Mihime Karya Mori Oogai. Jurnal Studi Jepang, 1(1), 1-12.

Hendra, D. (2018). Analisis Pemikiran Henri Levebvre Tentang Ruang Dalam Arsitektur Modern: Suatu Perspektif Sosiologis. Jurnal Ilmiah Mimbar Demokrasi, 17(2), 178-189. https://doi.org/10.21009/jimd.v17i2.9092

Kartikasari, R., Anoegrajekti, N., \& Maslikatin, T. (2013). Realitas Sosial Dan Representasi Fiksimini Dalam Tinjauan Sosiologi Sastra. Publika Budaya, 2(1), 50-57.

Modarres, A. (2005). Alienation, Resistance, and Transnationalism. Theory and Policy, December.

Nugroho, S. A. (2018a). Unwarranted Students: Emergence of Indonesian Migrant Student-Workers in South Korea. Hankuk University of Foreign Studies.

Nugroho, S. A. (2018b). Becoming Migrant Student-Workers : Indonesian Migrant Workers ' Strife to Break their Marginal Identity. A New Approach to Korean Language and Culture Education in the Age of Multiculturalism and Diversification, 1-20.

Prayoga, E. A., \& Handoyo, P. (2014). Eksploitasi Dan Alienasi Buruh Surveyor Di Lembaga Survei Produk "X" Di Surabaya. Paradigma, 2(1), 1-8.

Putranto, I. E. (2011). Dekonstruksi Identitas (Neo)Kolonial: Sebuah Agenda Teologi Postkolonial. Melintas, 27(3), 311-324. https://doi.org/10.26593/mel.v27i3.297.311-324

Rahajeng, A., Lordason, Y. P., \& Ardiyansyah, Y. (Eds.). (2018). TKI Berdaya Melalui Karya. In Familiar Stranger : Anthology of Poems and Short Stories by Indonesian Migrant Workers. Sanggar Budaya Budi Rahayu. 
Ritzer, G. (2012). Teori Sosiologi: Dari Sosiologi Klasik sampai Perkembangan Terakhir Postmodern (8th ed.). Pustaka Pelajar.

Ritzer, G., \& Goodman, J. D. (2004). Teori Sosiologi Modern. Kencana.

Salam, A. (2008). Pengajaran Sastra dan Politik Kebudayaan. INSANIA : Jurnal Pemikiran Alternatif Kependidikan, 13(3), 369-381. https://doi.org/10.24090/insania.v13i3.303

Samaluk, B. (2015). Migrant workers' engagement with labor market intermediaries in Europe: symbolic power guiding transnational exchange. Work, Employment $\mathcal{E}$ Society, 30(3), 455-471. https://doi.org/10.1177/0950017015594968

Seidman, S. (2013). Contested Knowledge Social Theory Today. Wiley-Blackwell.

SHE, R.-T. (2014). Invisible Bottom: The Underclass experiences in Migrant Workers Poetry. Jurnal of Notong University, 04(Social Science Edition).

Shervington, L. (2019). In Pursuit of the "Ideal Migrant": The Alienation of idealization in the Migrant Experience. 13th International Conference on Language, Literature, Culture, and Education, 42-48.

Storey, J. (2014). From popular culture to everyday life. In From Popular Culture to Everyday Life. https://doi.org/10.4324/9780203077023

Sun, W. (2012). Subalternity with Chinese characteristics: Rural migrants, cultural activism, and digital video filmmaking. Javnost, 19(2), 83-99. https://doi.org/10.1080/13183222.2012.11009086

Von Braun, J., \& Gatzwiler, F. W. (2014). Marginality-An Overview and Implications for Policy. In F. W. Gatzweiler \& H. Baumüller (Eds.), Marginality: Addressing the Nexus of Poverty, Exclusion, and Ecology (pp. 27-40). Springer Science + Business Media B.V. https://doi.org/10.1007/978-94-007-7061-4_2

Young, R. J. C. (2003). Postcolonialism: A Very Short Introduction. OUP Oxford. https://books.google.co.id/books?id=fw2wzntAWrYC 